\title{
Saproxylic beetles in non-intervention and coppice-with-standards restoration management in Meerdaal forest (Belgium): an exploratory
}

\section{analysis}

\author{
Kris Vandekerkhove ${ }^{(1)}$, \\ Arno Thomaes ${ }^{(1)}$, \\ Luc Crèvecoeur ${ }^{(2)}$, \\ Luc De Keersmaeker ${ }^{(1)}$, \\ Anja Leyman ${ }^{(1)}$, \\ Frank Köhler ${ }^{(3)}$
}

\begin{abstract}
For many centuries, coppice-with-standards management was applied in the mixed oak stands of Meerdaal forest (Belgium). Over the last century, these stands were gradually converted to high forest. On an area of 20 ha, the coppice-with-standards management is being restored, with specific adaptations for biodiversity (conservation of dead wood and veteran trees). A survey of saproxylic beetles was performed at 8 locations in the forest, including one site within the coppice-with-standards restoration. This survey not only allowed an evaluation of the saproxylic beetle richness of the forest complex, but also made exploratory observations on the effect of this type of management, as compared to non-intervention, on species richness and composition of saproxylic beetles. The results show that the overall species richness in the forest complex was quite high and comparable to forest reserves in Germany. Both coppice-with-standards and high forest options appear to be equally speciesrich, but consist of different communities, both containing specific, rare and notable species, with more thermophilous and light-demanding species in the coppice-with-standards plot. Based on these observations we suggest that a diversified management approach may be the most suitable to conserve and enhance diverse saproxylic beetle communities in formerly intensively managed semi-natural woodlands. This could include areas of active conservation management aimed at producing open-canopy stands with considerable amounts of sun-exposed deadwood, combined with areas of non-intervention in a matrix of multifunctional forests, where conservation of dead wood and veteran trees is fully incorporated in the management.
\end{abstract}

Keywords: Coppice-with-standards, Saproxylic Beetles, Insect Biodiversity, Type of Management, Active Conservation Management

\section{Introduction \\ There has been some debate as to whe- ther non-intervention is always the best management option for conserving biodi- versity, especially in former traditionally managed landscapes (e.g., Schnitzler 2014 versus Agnoletti 2014). For saproxylic bee- tles, the amount and variability of dead \\ wood, especially coarse woody debris (CWD) is considered to be the most impor- tant factor determining species richness (Martikainen et al. 2000, Brunet \& Isacsson 2009, Müller \& Bütler 2010, Stokland et al. 2012, Lassauce et al. 2011). Strict reserves (with non-intervention management, also called a "hands-off approach") contain or}

(1) Research Institute for Nature and Forest (INBO). Gaverstraat 4, 9500 Geraardsbergen (Belgium); (2) Provinciaal Natuurcentrum, Craenevenne 86, 3600 Genk (Belgium); (3) Koleopterologisches Forschungsbüro, Strombergstraße 22a, 53332 Bornheim (Germany)

@ Kris Vandekerkhove (kris.vandekerkhove@inbo.be)

Received: Aug 31, 2015 - Accepted: Feb 11, 2016

Citation: Vandekerkhove K, Thomaes A, Crèvecoeur L, De Keersmaeker L, Leyman A, Köhler F (2016). Saproxylic beetles in non-intervention and coppice-with-standards restoration management in Meerdaal forest (Belgium): an exploratory analysis. iForest 9: 536-54510. doi: 10.3832/ifor1841-009 [online 2016-03-25]

Communicated by: Tomas Vrska build up greater quantities and a higher diversity of dead wood than regularly managed forests (e.g., Vandekerkhove et al. 2009a) and correspondingly richer communities of saproxylic beetles (Müller et al. 2007, Paillet et al. 2010, Lachat et al. 2013). Non-intervention is therefore strongly advocated for the conservation of saproxylic communities, including saproxylic beetles (Martikainen et al. 2000, Parviainen et al. 2000, Müller et al. 2007, Bütler \& Lachat 2009, Bouget et al. 2014). Such studies, however, often focus on Boreal and Alpine forests, or on beech-dominated forest types.

For forests with a long management history, especially those where coppice management and forest grazing have resulted in open-canopy woodlands, often in lowland and thermophilic oak forests, the "handsoff" strategy is challenged. Hédl et al. (2010) came to the conclusion that spontaneous succession in thermophilic oak forests led to more common mesic forest types, resulting in the loss of many species 
that are specific to this forest type. They suggested reintroducing active coppice management or forest grazing to reverse the succession and restore the specific plant communities of traditionally managed oak forests. Other studies also indicate the loss of vascular plant species richness when coppice-with-standards forests are converted to high forest (Van Calster et al. 2008, Baeten et al. 2009). The positive effects of traditional coppicing on breeding birds and butterflies are often described (Buckley 1992, Fuller \& Warren 1996) but are also debated (Hambler \& Speight 1995). In the case of saproxylic beetles, it is argued that non-intervention is not always the best choice, especially in these old oakdominated forests, as they contain many thermophilous species adapted to the open-grown status of their habitat.

Open canopy conditions - regularly occurring in coppice-with-standards forests result in specific abiotic conditions, with higher summer temperatures in sun-exposed areas that may be essential for the survival of certain thermophilous species. In addition to the dead-wood resource, temperature is assumed to be a crucial driver of the diversity of saproxylic beetles (Lachat et al. 2012, Vodka \& Cížek 2013, Müller et al. 2014). Higher summer temperatures may even compensate for lower dead wood amounts (Köhler 2014, Müller et al. 2014).

Gärdenfors \& Baranowski (1992) concluded that $70 \%$ of the Swedish red-listed saproxylic beetles living on oaks preferred sun-exposed habitat and only $16 \%$ preferred dense stands (while this was the opposite for beech-related species). Several studies (Franc \& Götmark 2008, Widerberg et al. 2012, Gough et al. 2014) concluded that a partial opening up of old oak stands might increase the species richness of saproxylic beetles. Some authors even stated that natural succession might be a threat to the specific species community and that a "hands-off" conservation strategy was the "worst solution" and "especially damaging" when applied to traditionally managed woodlands, and should therefore be avoided (Sebek et al. 2013, Miklín \& Cížek 2014, Horak et al. 2014). These studies mainly focus on former wood pastures, still containing old open-grown veteran trees being gradually overgrown by understorey trees following the cessation of mowing and grazing (Ranius \& Jansson 2000, Franc \& Götmark 2008, Gough et al. 2014, Horak et al. 2014) or interplanted with spruces (Widerberg et al. 2012). However, few studies are known which actually compare the effect of management alternatives (Lassauce et al. 2012, Sebek et al. 2015) or natural disturbances (Bouget 2005) on the species richness of saproxylic beetles in former coppice-with-standards oak woodlands. Some authors advocated non-intervention (Hambler \& Speight 1995 , Lassauce et al. 2012), while others - often focusing on thermophilous species - called for reactivation of neglected coppice (Barbalat \& Gétaz 1999, Sebek et al. 2015).

In 2010-2011, a survey of saproxylic beetles was performed in the Meerdaal forest (Belgium), a relatively large ancient woodland site consisting mainly of uneven aged mixed oak stands (Quercus robur and Quercus petraea) that originated from a former coppice-with-standards regime. This survey was part of a larger project to evaluate whether forests in Northern Belgium, with their long history of fragmentation and intensive management (Verhulst 1995, Tallier 2004, Hermy \& Verheyen 2007, Vandekerkhove et al. 2009b, De Keersmaeker et al. 2015), still contained a high diversity of saproxylic beetles. In these forests very few veteran trees and virtually no dead wood were present (Vandekerkhove et al. 2011). Only in the past 30 to 40 years has the ecological value of dead wood and veteran trees gained attention in forest management and progressively been reinstated (Vandekerkhove et al. 2011). This management history and lack of continuity in dead wood may have resulted in an impoverished fauna, containing only good dispersers with limited substrate requirements, but lacking the more demanding and dispersal-limited species. However, no extensive datasets were available in Belgium to underpin this hypothesis, so specific surveys were set up to analyze the potential of forests in Northern Belgium for the conservation of saproxylic species in woodland sites that were considered to be of high potential for saproxylic beetles, including Meerdaal forest (Vandekerkhove et al. 2011). As the Meerdaal forest survey encompassed both unmanaged plots and the coppice-with-standard restoration, it also allowed for some preliminary observations on the effect of this management intervention on the saproxylic beetle community.

\section{Material and methods}

Meerdaal forest is an ancient woodland site, located $30 \mathrm{~km}$ east of Brussels, covering an area of approximately 1300 ha. The prevailing sub-Atlantic climate of this region has a total annual precipitation of ca. $821 \mathrm{~mm}$ (uniformly distributed over the year), and minimum and maximum average monthly temperatures of 2.5 and $17.2^{\circ} \mathrm{C}$, respectively, with a yearly average temperature of $9.7^{\circ} \mathrm{C}$. The forest is located on a slightly undulating plateau, with an elevation between 55 and $105 \mathrm{~m}$ a.s.l. Predominant soil types in Meerdaal forest are Luvisols (in the south) and Podzoluvisols (in the north), which developed in Pleistocene aeolian deposits of loamy loess on top of tertiary sandy formations (Baeyens et al. 1957). Main vegetation types are StellarioCarpinetum and Milio-Fagetum (sensu Noirfalise 1984) on Luvisols. On Podzoluvisols, the predominant vegetation type is FagoQuercetum (sensu Noirfalise 1984).

The forest mainly consists of unevenaged oak stands, complemented with beech (Fagus sylvatica) and conifer stands (mainly Pinus sylvestris - out of the scope of this study). The beech stands were mostly planted in the period 1850-1900, and are managed as high forest with regular thinning. For centuries, the oak stands were managed as coppice-with-standards but were gradually converted to high forest over the last 100 years (Vandekerkhove et al. 2016).

In 2010-2011 an intensive inventory of saproxylic beetles was performed in this forest complex. The sampling sites were specifically chosen at locations with a high "potential" for saproxylic beetles, i.e., on sites with relatively high amounts of dead wood and old and decaying trees. Also differences in light conditions were conside-

Tab. 1 - Overview of the sampling sites in Meerdaal forest.

\begin{tabular}{|c|c|c|c|c|}
\hline No & Description & $\begin{array}{l}\text { Sampling } \\
\text { year }\end{array}$ & $\begin{array}{l}\text { Basal area } \\
\left(\mathrm{m}^{2} \mathrm{ha}^{-1}\right)\end{array}$ & $\begin{array}{l}\text { Dead wood volume } \\
\qquad\left(\mathrm{m}^{3} \mathrm{ha}^{-1}\right)\end{array}$ \\
\hline 1 & $\begin{array}{l}\text { Mixed oak-hornbeam forest; dominant tree layer = oaks }(100-250 \text { years old }) \text { - strict } \\
\text { reserve since } 1995\end{array}$ & 2011 & 34.5 & 29.1 \\
\hline 2 & $\begin{array}{l}\text { Mixed oak-hornbeam forest; dominant tree layer = oaks }(100-250 \text { years old }) \text { - strict } \\
\text { reserve since } 1995\end{array}$ & 2011 & 35.5 & 26.6 \\
\hline 3 & $\begin{array}{l}\text { Coppice-with-standards restoration - standard trees of oak (100-250 years old) - } \\
\text { restoration cut in winter } 2010-2011\end{array}$ & 2011 & 12.9 & 21.0 \\
\hline 4 & Even-aged beech stand (145 years old) - strict reserve since 1995 & 2011 & 32.5 & 33.5 \\
\hline 5 & Even-aged beech stand (110 years old) - strict reserve since 1995 & 2010 & 24.5 & 18.5 \\
\hline 6 & $\begin{array}{l}\text { Mixed oak-hornbeam forest; dominant tree layer = oaks }(100-250 \text { years old }) \text { - strict } \\
\text { reserve since } 1995\end{array}$ & 2010 & 31.4 & 36.9 \\
\hline 7 & Beech tree alley (ca. 130 years old), outside but connected to the forest & 2010 & - & - \\
\hline 8 & $\begin{array}{l}\text { Mixed oak-hornbeam forest; dominant tree layer = oaks }(100-250 \text { years old }) \text { - strict } \\
\text { reserve since } 1995\end{array}$ & 2010 & 34.7 & 28.1 \\
\hline
\end{tabular}


red, covering both closed canopy non-intervention and open, sun-exposed sites.

In 8 localities (4 each year) a standardized survey was performed. It comprised of 6 non-intervention sites ( 4 oak and 2 beech stands), an old beech tree alley and one site in a coppice-with-standards restoration project (Tab. 1).

The non-intervention sites were located in strict forest reserves, 20-50 ha in size, that were established in 1995. The two beech non-intervention sites were evenaged, monospecific beech stands of 110 and 145 years old, previously managed as high forest and regularly thinned. The oak stands consisted of mixed high forest originating from coppice-with-standards, with a relatively high number of standard trees. Since the 1950s, when coppicing was abolished, the oak stands have been managed as mixed, uneven-aged high forest with regular thinning and group felling. The stands are dominated by an uneven-aged layer of the former standard oak trees, between 100 and 250 years old, combined with a dense sub-canopy mainly of maple (Acer pseudoplatanus) and hazel (Corylus avellana). The stands in strict reserves have now been left unmanaged for over 15 years.

One sampling site was located in a mixed oak stand of 20 ha that was declared a "managed forest reserve" in 1998, in order to restore the coppice-with-standards management. This restoration was subdivided into eight subplots of 2-3 ha, of which one subplot was intensively thinned every second year in order to re-create the forest structure (species composition, stem density, diameter distribution and basal area) of 100-200 years before. Modifications to the traditional management are that veteran and dead trees present in the stand were all conserved, as was a share of the felling residues. Sampling of this site was performed within the coupe of winter 2010-2011, in which the basal area was reduced from ca. 25 to $13 \mathrm{~m}^{2} \mathrm{ha}^{-1}$. It is located adjacent to the coupe of 2008-2009.

The beech tree alley consisted of 120-150 year old beech trees, and is located outside but connected to the forest. It contains several moribund trees, with dead branches in the canopy and on the ground. Data on basal area and local dead wood volumes in Tab. 1 are derived and updated from dendrometric inventory data compiled in the forest reserves monitoring program (Vandekerkhove et al. 2003) and the management plan of the Meerdaal forest.

Beetle sampling was done from April to November and involved both active and passive sampling. The latter consisted of a window trap and a glue-ring, both attached to one dead or dying standing tree per site. Active sampling aimed to be comparable at each site and involved 3 sampling sessions of $1 / 2$ hour per site (in May, June and July) by two people performing sweep netting and beating tray catches on wood, fungi and shrubs and the collection and analysis of 5 wood-mould sieve samples (of comparable size) per site.

All Coleoptera were identified to the species level. They were subdivided into forest-related species versus eurytope and non-forest species. The forest-related species were divided between saproxylic and non-saproxylic species according to Köhler (2000). The saproxylic species were subsequently allocated to six substrate classes (Köhler 2000). These classes distinguish species living in the early decay stage of dead wood (wood), in highly decayed wood mould (mould), in decaying bird and insect nests (nest), in wood-decaying fungi (fungi), cambium feeders and predators living in and under bark (bark) and species primarily living or depending on sap run in living trees (sap run). The conservation status of the saproxylic species was assessed based on the Red Lists for Germany (Geiser 1998) and for Europe (Nieto \& Alexander 2010), as no Red List for Belgium exists. Indicator species for old-growth continuity were derived from the list developed by Müller et al. (2005).

The results of the survey allowed for an overall evaluation of the saproxylic beetle richness of the forest complex, but also to compare the separate sites, which were all sampled in the same way.

Although the sampling setup was not originally designed to this purpose - the original aim was to evaluate the current overall saproxylic beetle richness of the forest complex -, this survey in Meerdaal forest also allowed to perform some exploratory observations on the saproxylic beetle richness of two conservation alternatives, non-intervention and restoration of coppice-with-standards, in a forest that was previously much more open and intensively managed for wood production.

Comparisons were made in a descriptive way, comparing total species richness, redlisted species richness, and the number, abundance and characteristics of the species that were exclusively found in one site. Comparability of the sites was further analyzed using ordination. Separate analyses were made for the complete dataset of saproxylic beetles using all sampling techniques (active and passive) and including only the standardized passive catch methods (glue ring and window trap). Presence/absence data was used with the Jaccard method as distance measure. A permutational multivariate analysis of variance (PERMANOVA) was performed using the Anderson method (Anderson 2001) to evaluate the effect of the following factors: (a) tree species; and (b) management (non-intervention, tree alley and coppicewith-standards). Effects of both variables were tested in separate models. As the sampling was spread over two years, we also checked for sampling year bias by running the PERMANOVA on the subset of non-intervention sites ( 2 oak, 1 beech per sampling year), and adding the factor "year" to the full model.
The Anderson method uses a permutation test with pseudo- $F$ ratios to fit linear models to distance matrices (Anderson 2001). PERMANOVA models were performed with 1000 permutations in $R$ 3.2.2 ( $R$ Core Team 2015) using the library "Vegan" (Oksanen et al. 2013). The graphs were made with the Capmod function in Vegan.

\section{Results}

In total, 22390 adult beetles of 781 species were captured, of which 10583 individuals belonged to 294 species that are considered saproxylic according to Köhler (2000). Seventy-six of these saproxylic beetles are listed in the German Red List (Geiser 1998), of which four are in the "critically endangered" category (Aeletes atomarius, Triplax rufipes, Plectophloeus rhenanus and Anaspis garneysi), 21 are "endangered" and 51 are "vulnerable". One species living in brown rot wood-mould, Cerophytum elateroides, appears in the European Red List (Nieto \& Alexander 2010) in the category "vulnerable" (but "endangered" on the German Red List). Another species, Aeletes atomarius, is an indicator of dead wood continuity, the so-called "Urwald-relict-species" (Müller et al. 2005).

An overall descriptive comparison for the eight sampling sites is given in Tab. 2 . When comparing the total species richness (all beetle species, including ubiquists) in the eight sampling sites, similar figures of 230-280 species per plot were detected, except for site 7 (the tree alley) where 379 species were found. However, if we exclude non-forest-dwelling and non-saproxylic species, then the differences are much less pronounced, with numbers varying between 106 and 137. Beech and oak-dominated sites had comparable species richness, and open canopy sites ( 3 and 7) were not particularly richer than the closed-canopy sites (Tab. 2). Dominant tree species and site openness did not appear to determine the overall species richness of the different sampling sites, nor the number of red-listed species. Larger differences in abundance can be explained by one or two species being much more abundant in one of the sites. For the coppice-with-standards site, the ubiquist carabid beetles Bradycellus verbasci and Bradycellus harpalinus are much more abundant than in other plots and make up more than half of all captured specimen at this site. Also, when we compare the partitioning of species over different substrate types, we do not see any clear pattern related to tree species or sunexposure. (Fig. 1). Based on the literature (Köhler 2000, 2011, Bouget et al. 2014), it might be expected that open sites (i.e., coppice-with-standards restoration and tree alley) as compared to the closedcanopy non-intervention plots, would contain relatively more wood and bark related species preferring fresh sun-exposed substrate and less fungi-related species, the fungi being associated with more shaded and moist conditions. With regards to spe- 
Tab. 2 - Results for the 8 sampling sites, both on abundance (\#indiv) and species richness (\#spp), for all beetles, saproxylic beetles only, red-listed species (RL1: critically endangered; RL2: endangered; RL3: vulnerable) and for selected and subfamilies. Tree species and management codes: (Q-NI): oak stands with non-intervention; (Q-CWS): oak stands with coppice-with-standards management; (F-NI): beech stands with non-intervention; (F-TA): beech tree alley in open countryside.

\begin{tabular}{|c|c|c|c|c|c|c|c|c|c|c|}
\hline \multirow[b]{2}{*}{ Group } & Sampling site no. & 1 & 2 & 3 & 4 & 5 & 6 & 7 & 8 & \multirow[b]{2}{*}{ Total } \\
\hline & $\begin{array}{l}\text { Tree species } \\
\text { and management }\end{array}$ & Q-NI & Q-NI & Q-CwS & F-NI & F-NI & Q-NI & F-TA & Q-NI & \\
\hline \multirow[t]{2}{*}{ All Coleoptera } & \# indiv & 2267 & 1899 & 3220 & 2622 & 2739 & 3160 & 4678 & 1769 & 22354 \\
\hline & \# spp & 230 & 281 & 267 & 269 & 257 & 276 & 379 & 256 & 781 \\
\hline \multirow[t]{2}{*}{ All Saproxylic } & \# indiv & 1098 & 1310 & 859 & 2009 & 1576 & 1468 & 1456 & 807 & 10583 \\
\hline & \# spp & 114 & 137 & 111 & 134 & 106 & 118 & 131 & 117 & 294 \\
\hline \multirow[t]{2}{*}{ RL1 } & \# indiv & 0 & 0 & 28 & 149 & 64 & 1 & 5 & 19 & 266 \\
\hline & \# spp & 0 & 0 & 1 & 1 & 2 & 1 & 3 & 2 & 4 \\
\hline \multirow[t]{2}{*}{ RL2 } & \# indiv & 28 & 31 & 15 & 14 & 19 & 47 & 27 & 15 & 224 \\
\hline & \# spp & 5 & 8 & 8 & 2 & 4 & 6 & 3 & 4 & 21 \\
\hline \multirow[t]{2}{*}{ RL3 } & \# indiv & 74 & 206 & 110 & 90 & 340 & 207 & 208 & 83 & 1318 \\
\hline & \# spp & 17 & 29 & 11 & 18 & 22 & 18 & 25 & 19 & 51 \\
\hline \multirow[t]{2}{*}{ Staphylinidae } & \# indiv & 71 & 212 & 93 & 197 & 105 & 127 & 60 & 73 & 938 \\
\hline & \# spp & 26 & 24 & 17 & 26 & 17 & 21 & 21 & 16 & 52 \\
\hline \multirow[t]{2}{*}{ Buprestidae } & \# indiv & 4 & 0 & 216 & 0 & 0 & 0 & 0 & 0 & 220 \\
\hline & \# spp & 2 & 0 & 4 & 0 & 0 & 0 & 0 & 0 & 4 \\
\hline \multirow[t]{2}{*}{ Cerambycidae } & \# indiv & 19 & 8 & 35 & 9 & 18 & 3 & 14 & 22 & 128 \\
\hline & \# spp & 6 & 8 & 10 & 7 & 8 & 1 & 4 & 4 & 22 \\
\hline \multirow[t]{2}{*}{ Scolytinae } & \# indiv & 542 & 546 & 159 & 898 & 40 & 511 & 129 & 159 & 2984 \\
\hline & \# spp & 9 & 10 & 12 & 12 & 4 & 9 & 11 & 8 & 20 \\
\hline \multirow{2}{*}{$\begin{array}{l}\text { Latridiidae+Mycetopha- } \\
\text { gidae+Ciidae }\end{array}$} & \# indiv & 80 & 98 & 48 & 179 & 396 & 203 & 556 & 120 & 1680 \\
\hline & \# spp & 9 & 11 & 6 & 16 & 14 & 18 & 19 & 13 & 26 \\
\hline
\end{tabular}
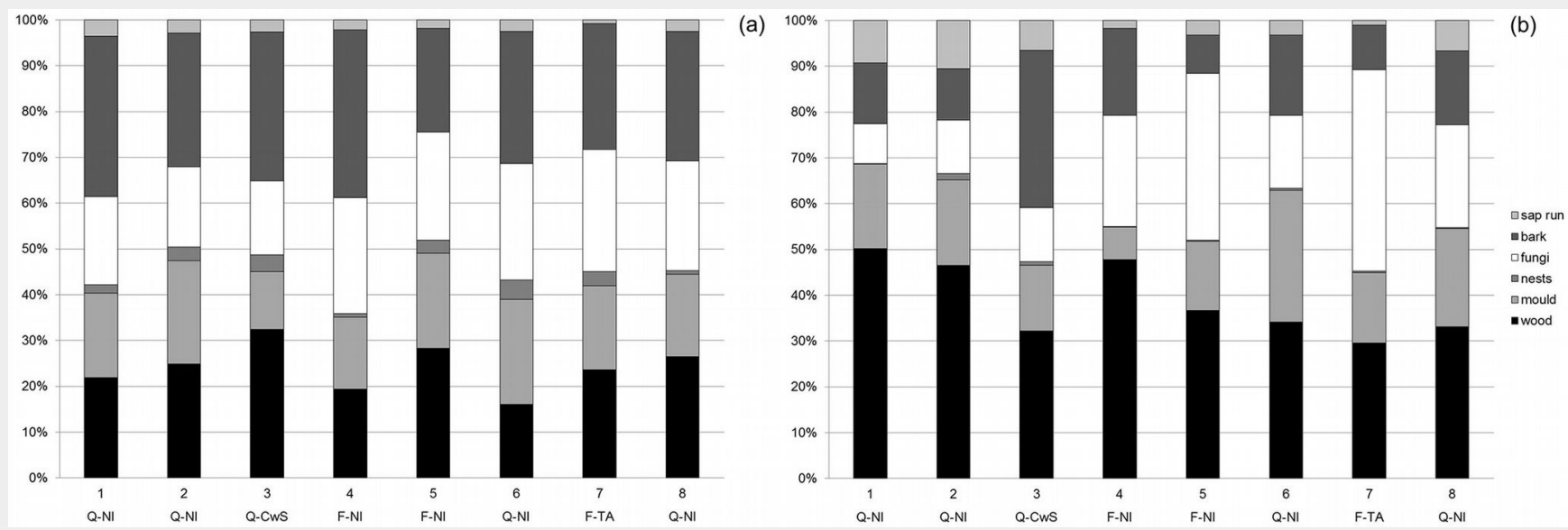

Fig. 1 - Relative share of species (a) and specimens (b) including both active and passive catches, allocated to different substrate classes (according to Köhler 2000) for the 8 sampling sites of Meerdaal forest. Tree species and management codes: (Q-NI): oak stands with non-intervention; (Q-CWS): oak stands with coppice-with-standards management: (F-NI): beech stands with non-intervention; (F-TA): beech tree alley in open countryside.

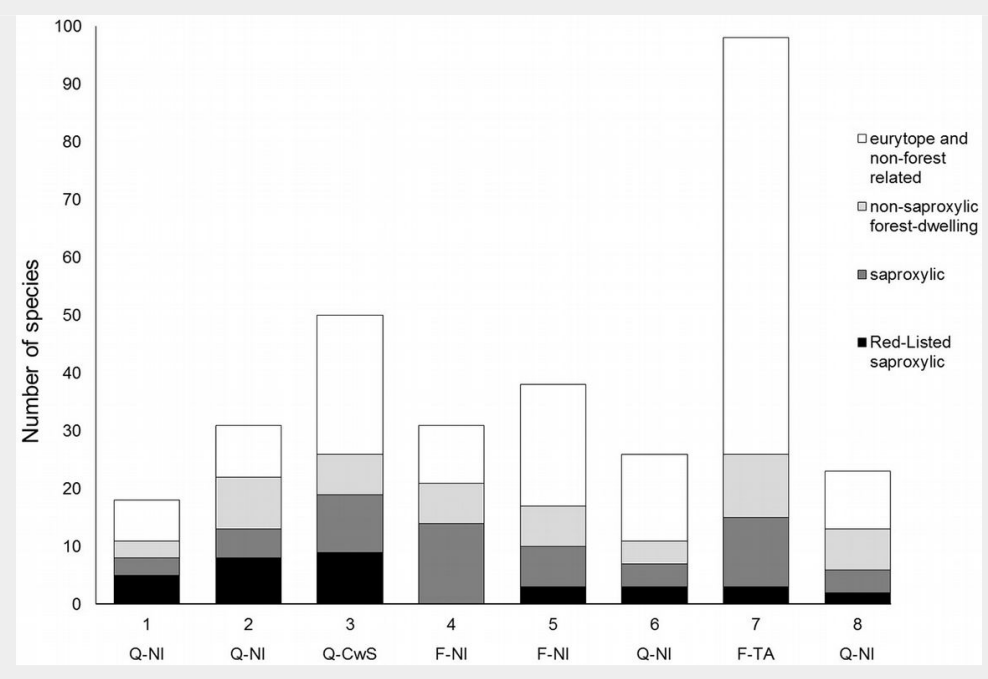

Fig. 2 - Number of exclusive Coleoptera species for every plot, subdivided in red-listed saproxylic species, non-redlisted saproxylic species, non-saproxylic forest-dwelling species and eurytope and non-forest beetle species (active+ passive catches). Tree species and management codes: (Q-NI): oak stands with non-intervention; (Q(wS): oak stands with coppice-with-standards management; (F-NI): beech stands with non-intervention; (F-TA): beech tree alley in open countryside. 
cies richness (Fig. 1a), the coppice-withstandards restoration appears to meet these expectations, but the tree alley does not. As for relative abundance (Fig. 1b), the coppice-with-standards restoration clearly contained relatively more bark-related species, but this can be attributed to the relative abundance of one species (Agrilus sulcicollis) that made up more than $10 \%$ of all captured saproxylic beetles in this plot. The tree alley showed a different pattern with more fungi-related individuals, also explained by the high abundance of two species (Octotemnus glabriculus and Cis castaneus).

However, differences did emerge when comparing the species richness and number of individuals for some selected families in Tab. 2. For Staphylinidae, the most species-rich family in this survey, including species of diverse habitat groups and both sun-exposed and shaded conditions, no obvious differences were apparent. Likewise, for Scolytinae, more exclusively linked to bark substrates, no specific link between diversity and tree species or sun-exposure was observed. However, for the families with a pronounced preference for sun-exposed wood, jewel beetles (Buprestidae) and longhorn beetles (Cerambycidae), the coppice-with-standards site appears to be richer than the other sites, both in species diversity and number of individuals. For jewel beetles in particular, the difference was striking. Although also sun-exposed, the beech alley did not show a similar pattern: species richness for the above-mentioned families was comparable to the non-intervention sites.

For families consisting mainly of small species living in saproxylic fungi and woodmould, often in shaded conditions, like Latriidae, Mycetophagidae and Ciidae, an inverse pattern could be observed, though less pronounced. For these families, the coppice-with-standards site showed the lowest figures, both in species richness and abundance.

We also checked the number of exclusive species for each site (Fig. 2). If comparing all beetle species, including non-forest and non-saproxylic species, then the beech alley unmistakably contained the highest number of exclusive species, as this site also captured many eurytope species from the open countryside. When considering only forest-dwelling and saproxylic species, then the coppice-with-standards site had the highest number of exclusive species for forest-related species, as well as saproxylic and red-listed saproxylic species. The species exclusively found in the coppice-withstandards plot included the longhorn beetles Xylotrechus rusticus, Xylotrechus antilope, Plagionotus detritus, Plagionotus arcuatus and Phymadotes alni. Other species were Cerophytum elateroides and the jewel beetles Agrilus biguttatus and Agrilus laticornis. All but one of the 92 specimens of Agrilus angustulus and all but 3 of 90 the specimens of Agrilus sulcicollis were caught

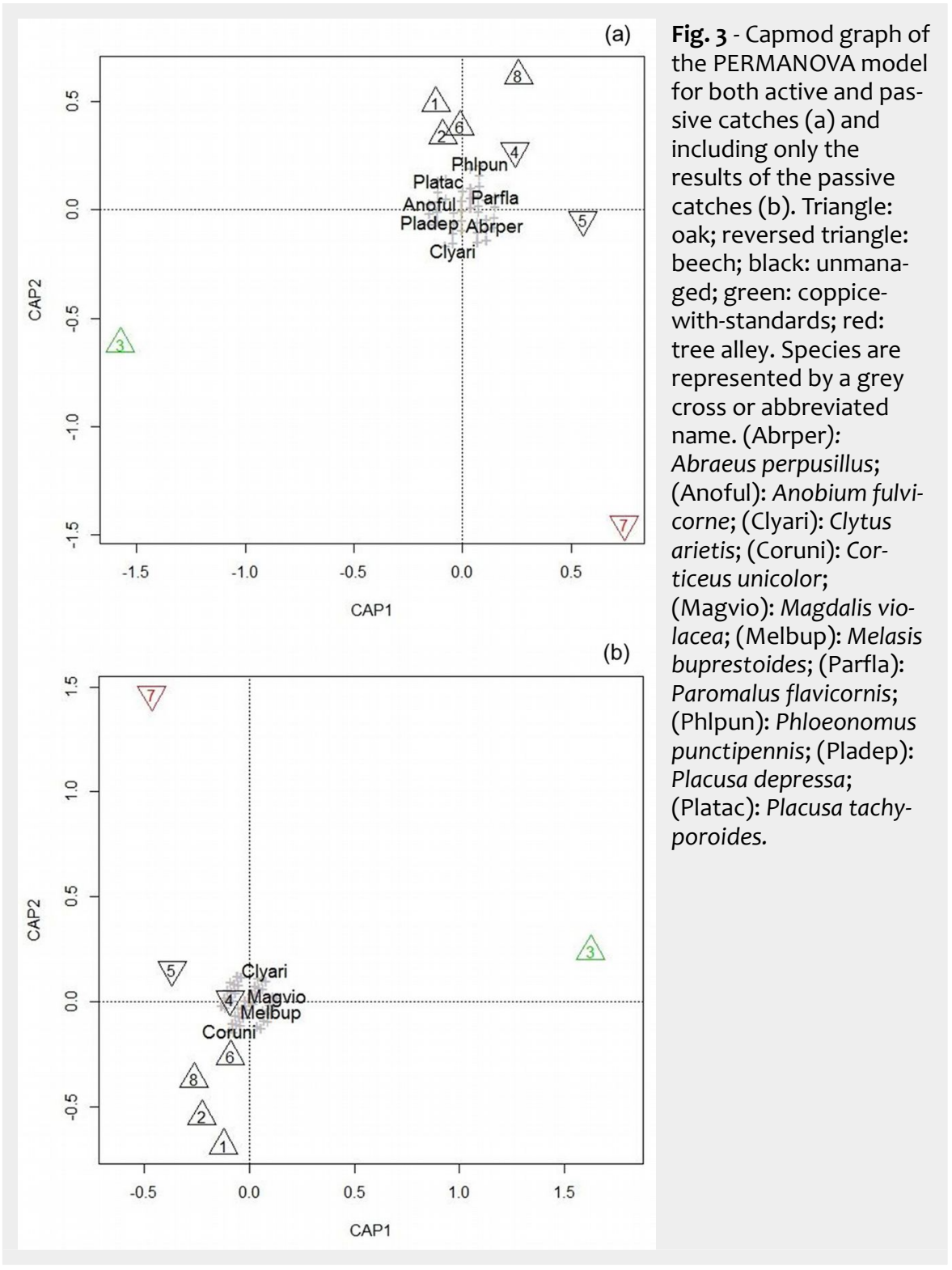

at this site.

The results of the statistical analysis are given in Fig. 3 and Tab. 3. The Capmodgraphs from the PERMANOVA model for both analyses (including and excluding the active catches) gave similar results: the unmanaged oak and beech stands are clustered together, whereas the beech alley and the coppice-with-standards plot were clearly divergent from the rest and each other.

The results of the model (Tab. 3) indicate that the "tree species" factor was not significant, whereas "management", distinguishing between non-intervention, coppi-

Tab. 3 - Results from the PERMANOVA model for both active and passive catches (a) and including only the results of the passive catches (b). $\left(^{*}\right): p<0.05$.

\begin{tabular}{llcll}
\hline Model & Factor & df & F & \multicolumn{1}{c}{$\mathbf{P}$} \\
\hline (a) Active + passive catches & Tree species & 1 & 0.99395 & 0.4945 \\
\cline { 2 - 5 } (b) Passive catches & Management & 2 & 1.5831 & 0.07393 \\
& Tree species & 1 & 1.1076 & 0.3986 \\
\cline { 2 - 5 } & Management & 2 & 1.5163 & $0.03397^{*}$ \\
\hline
\end{tabular}

ce-with-standards and the tree alley, apparently affects the species composition. When considering only passive catches, the factor "management" was significant, while for both active and passive catches it was marginally significant.

To interpret the axes of the ordination, the ten most influential species for these axes in the direction of plot 3 and 7 in the Capmod-graphs are listed in Tab. 4. Thermophilous species, especially longhorn beetles - further complemented by Agrilus species for the analysis with only passive catches - were prominent in the positioning of the CAP1 axis that strongly differen- 
Tab. 4 - Lists of the 10 most influential species determining the CAP1 and CAP2-axis of the ordination in the direction of plot 3 and 7 for both active and passive catches (left) and including only the results of the passive catches (right).

\begin{tabular}{llll}
\hline Passive + active catch & & Passive catch & \\
\hline CAP1 & CAP2 & CAP1 & CAP2 \\
\hline Mordella aculeata & Ptinella aptera & Malthodes marginatus & Cerylon ferrugineum \\
Platycerus caraboides & Dasytes plumbeus & Scaphisoma agaricinum & Melanotus villosus \\
Phymatodes alni & Diplocoelus fagi & Plagionotus detritus & Xyloterus domesticus \\
Xylotrechus rusticus & Sphindus dubius & Taphrorychus villifrons & Euplectus karsteni \\
Xylotrechus antilope & Sulcacis affinis & Agrilus biguttatus & Cetonia aurata \\
Plagionotus detritus & Dorcatoma robusta & Agrilus laticornis & Dacne bipustulata \\
Plagionotus arcuatus & Dorcus parallelipipedus & Aplocnemus impressus & Enicmus brevicornis \\
Crypturgus pusillus & Stereocorynes truncorum & Crypturgus pusillus & Bitoma crenata \\
Taphrorychus villifrons & Magdalis ruficornis & Phymatodes alni & Clytus arietis \\
Magdalis violacea & Clytus arietis & Placusa depressa & \\
\hline
\end{tabular}

tiated the coppice-with-standards from unmanaged plots, indicating that this axis can be linked to sun-exposure.

The results appeared not to be biased by the year of sampling. We tested the factor "sampling year" in a PERMANOVA on the subset of 6 non-intervention sites (2 oak, 1 beech every sampling year), both with and without tree species as a factor in the model, and with the two subset variants (with and without the active catches). Sampling year was not significant in all 4 cases. Also, when sampling year was added as an additional factor to the PERMANOVA model presented here, this factor was not significant and did not alter the outcome (results not shown).

\section{Discussion}

The overall species diversity of saproxylic beetles in Meerdaal forest was relatively quite high, both in quantity and quality of species. When compared with other forest reserves in Germany and Luxemburg that were surveyed in a similar way (Köhler 2014), Meerdaal forest had a greater than average total species richness of saproxylic beetles: 294 species compared to an average of 256 for 24 sites in Germany and Luxemburg. The number of 75 red-listed species was also in line with the average recorded in these 24 sites.

These figures were higher than expected as the relatively small size and high level of isolation of Meerdaal forest are less favorable for a rich saproxylic beetle community than in most comparison sites. It also has had a long history of very intensive management, with little or no deadwood remaining at the site (Vandekerkhove et al. 2016), and very few veteran trees. In 1913, barely 15 trees over $250 \mathrm{~cm}$ in girth occurred in the whole forest complex (Vandekerkhove et al. 2009b). It is uncertain whether saproxylic species managed to survive over past centuries in relic habitats like cavities in old coppice stools (Lassauce et al. 2012), dead branches in the standards or in pollard trees in the surrounding countryside (that have now almost all disappeared), or whether they have managed to recolonize the newly established favorable habitats from longer distances (Jonsson et al. 2005, Vandekerkhove et al. 2011, 2013).
Nevertheless, the presence of only one indicator species of dead wood continuity ("Urwald relic species" according to Müller et al. 2005) indicates that slow dispersers with high habitat requirements were under-represented. This is the case in most European lowland forests, including the German and Luxemburg reserves this site is compared with.

On the other hand, the Meerdaal forest complex now exhibits relatively large amounts of dead wood, especially in the forest reserves. There, the amounts are in the required range of $30-50 \mathrm{~m}^{3}$ per ha of dead wood for rich saproxylic communities (Müller \& Bütler 2010). The forest also contains a high density of very large trees: over 1200 individuals measure over 3 meters in girth, of which more than 500 are oak trees (Vandekerkhove et al. 2009b). Considering only these oaks, the average density $\left(0.35\right.$ trees ha $\left.{ }^{-1}\right)$ doubles the threshold of 0.15 trees ha ${ }^{-1}$ mentioned by Bergman et al. (2012) required to ensure a rich saproxylic oak fauna. In this context, dispersal-limited species whose habitat requirements are currently met, may still be missing, resulting in a so-called colonization or immigration credit (Hanski 2000, Jackson \& Sax 2009).

The inventory in Meerdaal forest, spread over 8 sites and two survey years, was designed to produce a first evaluation of the importance of the forest complex for saproxylic beetles. The survey was not originally set up to compare the effect of different management alternatives on species richness and abundance of saproxylic beetles. To draw full conclusions on this topic, a more equal distribution of the different management types, including regular management, and with more replications for each management type, is required.

Nevertheless, these results are sufficiently explicit to make preliminary observations on the species richness of saproxylic beetles in the analyzed situations. Species richness in the coppice-with-standards site appeared to be comparable to the non-intervention sites, but species composition in the former was substantially different from both the closed-canopy non-intervention sites and the equally sun-exposed tree al- ley that was surveyed.

In the applied model, the "management" factor showed to be significant or marginally significant (with and without active catches), while the "tree species" factor was clearly not significant, indicating that the level of sun-exposure was a stronger determinant of species composition in saproxylic beetles than the dominant tree species.

Due to the limitations of the experimental setup we must be cautious with the interpretation of these results. We further tested our observations by analyzing more variants of the model, adding non-saproxylic species and using abundance instead of presence-absence data, again excluding and including the active sampling techniques. For all these variants, the results remained similar: the consistency of the results, irrespective of the different data subsets used, supports our assumption that the "management" factor is a true effect that shapes the beetle species composition. Nevertheless, the restrictions of the dataset only allow us to conclude that the effect is likely. Further research with full replicates should be undertaken to fully prove this effect.

Our observations indicate that the saproxylic beetle community on the coppicewith-standards restoration plot appears to be different from, but not necessarily richer than, that of the non-intervention plots. This observation apparently differs from other studies where saproxylic beetle richness of oak woodlands was found to be higher in sites with more open canopies.

Many of these studies focus on the restoration of abandoned wood pastures in Scandinavia. Ranius \& Jansson (2000) compared species richness of cavity-inhabiting saproxylic species on 18 oak sites in Sweden: next to tree size (girth), low canopy cover also increased the frequency of several species. Franc \& Götmark (2008) presented the results of a large experiment for saproxylic beetles in which non-intervention was compared to a specific "partial cutting" regime ( $25 \%$ of basal area, retaining both large and dead trees) in paired plots in 22 old oak sites in Southern Sweden. They found on average 35\% more species in the partially cut areas, but there was 
no difference in the species richness of redlisted species, only in the composition of exclusive species between the managed and the uncut areas. Widerberg et al. (2012) found an increase in species richness and abundance of oak-associated species when old oak trees closed in by spruce plantations were released. Gough et al. (2014) also concluded that clearing of regrowth in areas with veteran oaks was expected to increase species richness of vulnerable and specialist saproxylic beetle species. These results may apply particularly to the management history of the wood pastures, still containing old opengrown veteran trees but now being gradually shaded and suppressed by understorey trees, following the cessation of mowing and grazing management. These wood pastures are known to be very rich in saproxylic species, and are of particular interest to highly demanding species with low dispersal ability and living in woodmould of sun-exposed, hollow trees (Harding \& Rose 1986, Miklín \& Cížek 2014, Ranius $\&$ Jansson 2000). Natural succession in these situations would ultimately lead to shading and the suppression of the old oaks by late-successional species, which is detrimental to the rare saproxylic community specifically associated with veteran oaks. Restoration of more open canopy, while conserving the veteran oaks and dead wood, will clearly benefit these communities, while the newly arriving species of closed canopy forest will most likely survive in the immediate surroundings. In these circumstances, active conservation management may indeed result in higher species richness. However, Franc \& Götmark (2008) warned against too drastic and general application of these interventions. Too strong opening of the canopy may result in increased mortality of the old trees, and may also disadvantage many red-listed species preferring semi-open or closed canopies. They advised a differentiated management approach, including both active management and minimal intervention.

In the original coppice-with-standards forests that were later abandoned or converted to high forest, the situation was quite different: it is unclear what the composition of the saproxylic beetle communities of these intensively managed stands were, and how rich they were. They were also frequently sun-exposed, but contained no veteran trees and hardly any dead wood (Kirby 1992, Vandekerkhove et al. 2011). Cavities were mainly restricted to the old coppice stools that were frequently shaded. It can therefore be assumed that the saproxylic communities in these forests were different from the wood pastures, favoring species with higher dispersal capacity, more adapted to shade and less restricted by continuous sun-exposure, or able to also survive within sun-exposed parts of the upper canopy of closedcanopy forest phases.
Studies that focus on the specific effect of coppice and coppice-with-standards management (or neglect) on saproxylic beetle communities are scarce. A small-scale survey of overmature coppice by Barbalat \& Gétaz (1999), comparing freshly cut coupes with a 5-year-old coupe and undisturbed forest, concluded that the recent canopy openings were richer in species than the uncut areas and the 5-year-old coupe. However, they only sampled 4 beetle families, which mainly contained thermophilous species (Buprestidae, Cerambycidae, Lucanidae and Scarabaeidae). On the 5 year old coupe, where the canopy had closed again, the positive effect of the intervention was no longer observed. Sebek et al. (2015) also concluded that recently cleared areas in an overmature coppice forest showed a higher total species richness in saproxylic beetles, but not for red-listed species, and indicated that a longer time series would be needed to evaluate the effect in later stages of the coppice cycle. Unfortunately, these studies do not contain any information on dead wood amounts and composition before and after the intervention, making it impossible to evaluate the impact of the clearings on resource availability.

On the other hand, Lassauce et al. (2012) compared still operational coppice-withstandards forests with a mature (20 years old) coppice layer to abandoned stands of overmature (60 years old) coppice, concluding that the abandoned sites contained a significantly higher species richness. In this study, all saproxylic beetle families were taken into account. The higher species richness could be linked to a higher amount of dead wood. In this study, however, both treatments contained only closed-canopy stands.

Our results are most in line with the findings of Bouget (2005) who compared saproxylic beetle richness in recently created and unharvested windstorm gaps to undisturbed controls in French oak-hornbeam forests. He also found a comparable species richness in both situations, but with striking differences in species composition. Likewise, thermophilous species of the families Cerambycidae and Buprestidae were more present in the gaps than in the controls. He concluded that unharvested gaps, although not necessarily any richer in species, may help to increase the gammadiversity at the forest scale. This strong increase in Longhorn beetle and Jewel beetle richness and abundance in disturbance gaps (natural or artificial) was also observed for oak stands by Vodka et al. (2009), and occurs also in other tree species such as Norway spruce (Wermelinger et al. 2002).

Indeed, the combination of a dead wood resource, combined with a diversity of sunexposure, appear to be the key factors determining the beetle richness. Bouget et al. (2013) compared the species richness in over 150 managed and unmanaged oak and beech stands in France, concluding that dead wood diversity was the key habitat feature associated with species richness and composition of saproxylic beetle communities. Openness of the stand was equally important for the diversity of both common and rare species in oak, but not for rare species in beech.

Management interventions like coppicing intervene by both removing dead wood resources and generating gap openings. Depending on the amounts and composition of the dead wood resource, and the light conditions before and after the intervention, the combined effect can be positive or detrimental to the saproxylic beetle community, and may also change over time. In a young mature mixed oak hardwood forest in South-Carolina (USA), Ulyshen et al. (2004) created several small gaps, leaving most of the so-called "slash" (i.e., harvest residue) on site. They concluded that wood-dwelling insects initially benefited from the disturbance, but that the disturbed areas became less favorable with time. As the amount of dead wood decreased and the canopy re-closed, the abundance of insects decreased. After 6 years, the gaps showed lower abundances than the younger gaps and the surrounding undisturbed forest. If large and diverse dead wood resources are available and natural canopy disturbances are present, the positive effect of active intervention may apparently disappear even for thermophilous species. In Bialowieza, Gutowski (1986) found a lower species richness for the thermophilous Cerambycidae in the forest areas managed under a shelterwood regime compared with the unmanaged strict forest reserve.

Further detailed and focused research is needed in active and former coppice-withstandards forests to obtain a better understanding of the saproxylic beetle communities of these woodlands, their requirements and the most suitable management regime for their conservation. In the meanwhile, it is advisable to apply differentiated management alternatives in these oak forests. In Meerdaal forest such an approach is applied to date in the mixed oak stands. It includes non-intervention strict reserves, active coppice-with-standards restoration and regular multifunctional silviculture with conservation of veteran trees and a gradual increase in dead wood. We consider this to be an effective approach to conserve and further develop the saproxylic species richness of the site.

\section{Conclusions}

The results of this exploratory survey of saproxylic beetles in the Meerdaal forest showed that the overall species richness in the forest complex was quite high and comparable to other strict forest reserves in Germany and Luxemburg.

The comparison of different sampling sites also provided indications of the effect of coppice-with-standards as compared to non-intervention, on species richness and 
composition of saproxylic beetles. Both management options appear to contain an equally species-rich community, including specific rare and endangered species. Species composition in the coppice-withstandards plot is however apparently different from the non-intervention sites and the beech tree alley plot.

The likely effect of the "management" factor, closely linked to light availability, appeared to be more important than the dominant tree species in the plot. These observations are based on an exploratory survey, and need further investigation and a more rigorous sampling design to draw full conclusions. The results do, however, support these preliminary conclusions and may be considered as a pilot for further specific investigations on the topic.

The observations also suggest that a diversified management approach may be the most suitable strategy to conserve and enhance diverse saproxylic beetle communities in formerly intensively managed semi-natural woodlands. This could include areas of non-intervention and active conservation management aimed at producing open-canopy stands with considerable amounts of sun-exposed deadwood, combined with multifunctional forest management conserving dead wood and veteran trees, as already suggested by Fuller \& Warren (1996). At the same time, one should always consider what aspects of biodiversity and natural value are desirable. Too strong a focus on maximizing species richness and specific target species may be detrimental to other species and other aspects of natural value like naturalness, authenticity or replaceability. Finally, as Götmark (2013) states, there is often not one correct management option. Focusing on a single option involves the risk of overlooking management alternatives.

\section{Acknowledgements}

Special thanks to Peter Van de Kerckhove, Marc Esprit, Bart Christiaens and Stefaan Goessens for the field measurements in the forest plots and their assistance in the installation of the sampling plots, and to Waltraud Fritz-Köhler for field work support during beetle sampling and database input on beetles.

We are very grateful to Dr. Peter Buckley for revising the language of the manuscript.

\section{References}

Agnoletti M (2014). Rural landscape, nature conservation and culture: some notes on research trends and management approaches from a (southern) European perspective. Landscape and Urban Planning 126: 66-73. - doi: 10.1016/j. landurbplan.2014.02.012

Anderson MJ (2001). A new method for non-parametric multivariate analysis of variance. Austral Ecology 26: 32-46. - doi: 10.1111/j.1442-9993. 2001.01070.pp.x

Baeten L, Bauwens B, De Schrijver A, De Keersmaeker L, Van Calster $\mathrm{H}$, Vandekerkhove $\mathrm{K}$,
Roelandt B, Beeckman H, Verheyen K (2009). Compositional changes (1954-2000) in the forest herb layer following the cessation of coppice-with-standards management and soil acidification. Applied Vegetation Science 12: 187-197. doi: 10.1111/j.1654-109X.2009.01013.x

Baeyens L, Tavernier R, Scheys G (1957). De Belgische bodemkaart, kaartblad 103E (HammeMille) [Belgian soil map, Sheet 103E (HammeMille)]. Comite voor het Opnemen van Bodemkaart en de Vegetatiekaart van Belgie, Gent, Belgium, pp. 57. [in Dutch]

Barbalat S, Gétaz D (1999). Influence de la remise en exploitation de taillis-sous-futaie sur la faune entomologique [Influence of renewed coppicing with standards on the entomological fauna]. Schweizerische Zeitschrift für Forstwesen 150: 429-436. [in French] - doi: 10.3188/szf. 1999.0429

Bergman K-O, Jansson N, Claesson K, Palmer MW, Milberg P (2012). How much and at what scale? Multiscale analyses as decision support for conservation of saproxylic oak beetles. Forest Ecology and Management 265: 133-141. doi: 10.1016/j.foreco.2011.10.030

Bouget C (2005). Short-term effect of windstorm disturbance on saproxylic beetles in broadleaved temperate forests: Part I. Do environmental changes induce a gap effect? Forest Ecology and Management 216: 1-14. - doi: 10.101 6/j.foreco.2005.05.037

Bouget C, Larrieu L, Nusillard B, Parmain G (2013). In search of the best local habitat drivers for saproxylic beetle diversity in temperate deciduous forests. Biodiversity and Conservation 22: 2111-2130. - doi: 10.1007/s10531-013-05 31-3

Bouget C, Parmain G, Gilg O, Noblecourt T, Nusillard B, Paillet Y, Pernot C, Larrieu L, Gosselin F (2014). Does a set-aside conservation strategy help the restoration of old-growth forest attributes and recolonization by saproxylic beetles? Animal Conservation 17: 342-353. - doi: 10.1111/ac v.12101

Brunet J, Isacsson G (2009). Restoration of beech forest for saproxylic beetles - effects of habitat fragmentation and substrate density on species diversity and distribution. Biodiversity and Conservation 18: 2387-2404. - doi: 10.1007/ s10531-009-9595-5

Buckley GP (1992). Ecology and management of coppiced woodlands. Chapman and Hall, London, UK, pp. 336.

Bütler R, Lachat T (2009). Wälder ohne Bewirtschaftung: eine Chance für die saproxylische Biodiversität [Unmanaged forests: an opportunity for the saproxylic biodiversity]. Schweizerische Zeitschrift für Forstwesen 160: 324-333. [in German] - doi: 10.3188/szf.2009. 0324

De Keersmaeker L, Onkelinx T, De Vos B, Rogiers $\mathrm{N}$, Vandekerkhove K, Thomaes A, De Schrijver A, Hermy M, Verheyen K (2015). The analysis of spatio-temporal forest changes (1775-2000) in Flanders (northern Belgium) indicates habitatspecific levels of fragmentation and area loss. Landscape Ecology 30: 247-259. - doi: 10.1007/s1 0980-014-0119-7

Franc N, Götmark F (2008). Openness in management: hands-off vs. partial cutting in conservation forests, and the response of beetles.
Biological Conservation 141: 2310-2321. - doi: 10.1016/j.biocon.2008.06.023

Fuller RJ, Warren MS (1996). Management for biodiversity in British woodlands - striking a balance. British Wildlife 7: 26-37.

Geiser R (1998). Rote liste der Käfer (Coleoptera) [Red list of beetles (Coleoptera)]. In: "Rote Liste gefärdeter Tiere Deutschlands" (Bundesanstalt für Naturschutz ed). BfN, BonnBad Godesberg, Germany, pp. 168-230. [in German]

Gough L, Birkemoe T, Sverdrup-Thygeson A (2014). Reactive forest management can also be proactive for wood-living beetles in hollow oak trees. Biological Conservation 180: 75-83. doi: 10.1016/j.biocon.2014.09.034

Gutowski JM (1986). Species composition and structure of the communities of longhorn beetles (Coleoptera: Cerambycidae) in virgin and managed stands of Tilio-Carpinetum stachyetosum association in the Bialowieza Forest (NE Poland). Journal of Applied Entomology 102: 380-391. - doi: 10.1111/j.1439-0418.1986.tboo93 $6 . x$

Gärdenfors U, Baranowski R (1992). Skalbaggar anpassade till öppna respective slutna ädellövskogar föredrar olika trädslag [Beetles living in open deciduous forests prefer different tree species than those living in dense forests]. Entomologisk Tidskrift 113: 1-11. [in Swedish]

Götmark F (2013). Habitat management alternatives for conservation forests in the temperate zone: review, synthesis, and implications. Forest Ecology and Management 306: 292-307. doi: 10.1016/j.foreco.2013.06.014

Hambler C, Speight MR (1995). Biodiversity conservation in Britain: science replacing tradition. British Wildlife 6: 137-147.

Hanski I (2000). Extinction debt and species credit in boreal forests: modeling the consequences of different approaches to biodiversity conservation. Annales Zoologici Fennici 37: 271-280. [online] URL: http://www.jstor.org/stable/2373 5720

Harding PT, Rose F (1986). Pasture woodlands in Lowland Britain: a review of their importance for wildlife conservation. Institute of Terrestrial Ecology, Huntingdon, UK, pp. 89. [online] URL: http://nora.nerc.ac.uk/5146/1/Pasture woodlan d.pdf

Hermy M, Verheyen K (2007). Legacies of the past in the present day forest biodiversity: a review of past land-use effects on forest plant species composition and diversity. Ecological Restoration 22: 361-371. - doi: 10.1007/s11284007-0354-3

Horak J, Vodka S, Kout J, Halda JP, Bogusch P, Pech P (2014). Biodiversity of most dead wooddependent organisms in thermophilic temperate oak woodlands thrives on diversity of open landscape structures. Forest Ecology and $\mathrm{Ma}$ nagement 315: 80-85. - doi: 10.1016/j.foreco.20 13.12.018

Hédl R, Kopecky M, Komarek J (2010). Half a century of succession in a temperate oakwood: from species-rich community to mesic forest. Diversity and Distributions 16: 267-276. - doi: 10.1111/j.1472-4642.2010.00637.x

Jackson ST, Sax DF (2009). Balancing biodiversity in a changing environment: extinction debt, immigration credit and species turnover. 
Trends in Ecology and Evolution 25: 153-160. doi: 10.1016/j.tree.2009.10.001

Jonsson BG, Kruys N, Ranius T (2005). Ecology of species living on dead wood - lessons for dead wood management. Silva Fennica 39: 289-309. doi: $10.14214 /$ sf.390

Kirby K (1992). Accumulation of dead wood - a missing ingredient in coppicing? In: "Ecology and Management of Coppiced Woodlands" (Buckley G ed). Chapman and Hall, London, UK, pp. 99-112. - doi: 10.1007/978-94-011-2362-4_6 Köhler F (2000). Totholzkäfer in Naturwaldzellen des Nördlichen Rheinlandes. Vergleichende Studien zur Totholzkäferfauna Deutschlands und Deutschen Naturwaldforschung [Dead wood beetles in strict forest reserves of the Northern Rheinland. Comparative studies of dead wood beetle fauna of Germany and German forest reserves research]. Schriftenreihe LÖBF/LAfAO NRW 18, Recklinghausen, Germany, pp. 351. [in German]

Köhler F (2011). Die Totholzkäfer (Coleoptera) des Naturwaldreservates "Enneschte Bësch" (2007-2009) [The dead wood beetles (Coleoptera) of strict forests reserve "Enneschte Bësch" (2007-2009)]. In: "Naturwaldreservate in Luxemburg, Band 8. Zoologische und botanische Untersuchungen Enneschte Bësch 2007-2010" (Murat D ed). Naturverwaltung Luxemburg, Luxemburg, pp. 78-135. [in German]

Köhler F (2014). Die klimabedingte Veränderung der Totholzkäferfauna (Coleoptera) des nördlichen Rheinlandes. Analysen zur Gesamtfauna und am Beispiel von Wiederholungsuntersuchungen in ausgewählten Naturwaldzellen [Climate related changes of dead wood beetle fauna (Coleoptera) of the Northern Rheinland. Analyses of the total fauna and using exemples of repeated surveys in selected strict forest reserves]. Landesbetrieb Wald und Holz Nordrhein-Westfalen, Münster, Germany, pp. 198. [in German]

Lachat T, Wermelinger B, Gossner M, Bussler H, Isacsson G, Müller J (2012). Saproxylic beetles as indicator species for dead-wood amount and temperature in European beech forests. Ecological Indicators 23: 323-331. - doi: 10.1016/j.eco lind.2012.04.013

Lachat T, Bouget C, Bütler R, Müller J (2013). Dead wood: quantitative and qualitative requirements for the conservation of saproxylic biodiversity In: "Integrative approaches as an opportunity for the conservation of forest biodiversity" (Kraus D, Krumm F eds). European Forest Institute, EFI-ENT, Freiburg, Germany, pp. 92-102.

Lassauce A, Paillet Y, Jactel H, Bouget C (2011). Deadwood as a surrogate for forest biodiversity: meta-analysis of correlations between deadwood volume and species richness of saproxylic organisms. Ecological Indicators 11: 1027-1039. - doi: 10.1016/j.ecolind.2011.02.004 Lassauce A, Anselle P, Lieutier F, Bouget C (2012). Coppice-with-standards with an overmature coppice component enhance saproxylic beetle biodiversity: a case study in French deciduous forests. Forest Ecology and Management 266: 273-285. - doi: 10.1016/j.foreco.2011. 11.016

Martikainen P, Siitonen J, Punttila P, Kaila L,
Rauh J (2000). Species richness of Coleoptera in mature managed and old-growth boreal forests in southern Finland. Biological Conservation 94: 199-209. - doi: 10.1016/Sooo6-3207 (99)00175-5

Miklín J, Cížek L (2014). Erasing a European biodiversity hot-spot: open woodlands, veteran trees and mature forests succumb to forestry intensification, logging, and succession in a UNESCO Biosphere Reserve. Journal for Nature Conservation 22: 35-41. - doi: 10.1016/j.jnc.2013. 08.002

Müller J, Bütler R (2010). A review of habitat thresholds for dead wood: a baseline for management recommendations in European forests. European Journal of Forest Research 129: 981992. - doi: 10.1007/s10342-010-0400-5

Müller J, Büssler H, Bense $U$, Brustel $\mathrm{H}$, Flechtner G, Fowles A, Kahlen M, Möller G, Mühle $H$, Schmidl J, Zabransky P (2005). Urwald relict species - saproxylic beetles indicating structural qualities and habitat tradition. Waldökologie Online 2: 106-113. [online] URL: http://www. afsv.de/docs/literatur/waldoekologieonline_hef t2.html

Müller J, Hothorn T, Pretzsch H (2007). Longterm effects of logging intensity on structures, birds, saproxylic beetles, and wood-inhabiting fungi in stands of European Fagus sylvatica L. Forest Ecology and Management 242: 297-305. doi: 10.1016/j.foreco.2007.01.046

Müller J, Brustel H, Brin A, Bussler H, Bouget C, Obermaier E, Heidinger I, Lachat T, Förster B, Horak J, Prochazka J, Köhler F, Larrieu L, Bense U, Isacsson G, Zapponi L, Gossner M (2014). Increasing temperature may compensate for lower amounts of dead wood in driving richness of saproxylic beetles. Ecography 38: 499509. - doi: 10.1111/ecog.00908

Nieto A, Alexander KNA (2010). European red list of saproxylic beetles. Publications Office of the European Union, Luxembourg, Luxemburg, pp. 48.

Noirfalise A (1984). Forêts et stations forestières en Belgique [Forests and forest site types in Belgium]. Presses Agronomiques, Gembloux, Belgium, pp. 236. [in French]

Oksanen J, Guillaume Blanchet F, Kindt R, Legendre P, Minchin PR, O'Hara RB, Simpson GL, Solymos P, Henry M, Stevens H, Wagner H (2013). Vegan: community ecology package. $R$ package version 2: 1-8. [online] URL: http:// CRAN.R-project.org/package=vegan

Paillet $Y$, Bergès L, Hjältén J, Odor $P$, Avon C, Bernhardt-Römermann M, Bijlsma RJ, De Bruyn L, Fuhr M, Grandin U, Kanka R, Lundin L, Luque $S$, Magura T, Matesanz S, Mészáros I, Sebastià MT, Schmidt W, Standovár T, Tóthmérész B, Uotila A, Valladares F, Vellak K, Virtanen R (2010). Biodiversity differences between managed and unmanaged forests: meta-analysis of species richness in Europe. Conservation Biology 24: 101-112. - doi: 10.1111/j.1523-1739.2009.013 99. $x$

Parviainen J, Bücking W, Vandekerkhove K, Päivinen R, Schuck A (2000). Strict forest reserves in Europe: efforts to enhance biodiversity and research on forests left for free development in Europe (EU-COST-action E4). Forestry 73: 107118. - doi: 10.1093/forestry/73.2.107

R Core Team (2015). R: a language and environ- ment for statistical computing. R Foundation for Statistical Computing, Vienna, Austria. [online] URL: https://www.R-project.org/

Ranius T, Jansson N (2000). The influence of forest regrowth, original canopy cover and tree size on saproxylic beetles associated with old oaks. Biological Conservation 95: 85-94. - doi: 10.1016/S0006-3207(00)00007-0

Schnitzler A (2014). Towards a new European wilderness: embracing unmanaged forest growth and the decolonisation of nature. Landscape and Urban Planning 126: 74-80. - doi: 10.1016/j.landurbplan.2014.02.011

Sebek P, Altman J, Platek M, Cízek L (2013). Is active management the key to the conservation of saproxylic biodiversity? Pollarding promotes the formation of tree hollows. PLoS ONE 8 (3): e60456. - doi: 10.1371/journal.pone.006 0456

Sebek P, Bace R, Bartos M, Benes J, Chlumska Z, Dolezal J, Dvorsky M, Kovar J, Machac O, Mikatova B, Perlik M, Platek M, Polakova S, Skorpik M, Stejskal R, Svoboda M, Trnka F, Vlasin M, Zapletal M, Cizek L (2015). Does a minimal intervention approach threaten the biodiversity of protected areas? A multi-taxa short-term response to intervention in temperate oak-dominated forests. Forest Ecology and Management 358: 80-89. - doi: 10.1016/j.foreco.2015.09.008 Stokland J, Siitonen J, Jonsson BG (2012). Biodiversity in dead wood. Cambridge University Press, Cambridge, UK, pp. 521. [online] URL: http://books.google.com/books?id=2jcgAwAAQ BAJ

Tallier P-A (2004). Forêts et propriétaires forestiers en Belgique de la fin du XVIIle siècle à 1914. Histoire de l'évolution de la superficie forestière, des peuplements, des techniques sylvicoles et des débouchés offerts aux produits ligneux [Forests and forest owners in Belgium from the end of the $18^{\text {th }}$ century until 1914 . History of the evolution of the forest area, stands, forestry techniques and wood products market]. Royal Academy of Sciences, Brussels, Belgium, pp. 764. [in French]

Ulyshen MD, Hanula JL, Horn S, Kilgo JC, Moorman C (2004). Spatial and temporal patterns of beetles associated with coarse woody debris in managed bottomland hardwood forests. Forest Ecology and Management 199: 259-272. doi: 10.1016/j.foreco.2004.05.046

Van Calster H, Baeten L, Verheyen K, De Keersmaeker L, Dekeyser S, Rogister JE, Hermy M (2008). Diverging effects of overstorey conversion scenarios on the understorey vegetation in a former coppice-with-standards forest. Forest Ecology and Management 256: 519-528. - doi: 10.1016/j.foreco.2008.04.042

Vandekerkhove K, De Keersmaeker L, Baeté H (2003). Methodology for Intensive monitoring of forest dynamics in strict forest reserves in Flanders (northern Belgium). Scripta Botanica Belgica 24: 93-103.

Vandekerkhove K, De Keersmaeker L, Menke N, Meyer P, Verschelde P (2009a). When nature takes over from man: dead wood accumulation in previously managed oak and beech woodlands in North-West- and Central Europe. Forest Ecology and Management 258: 425-435. doi: 10.1016/j.foreco.2009.01.055

Vandekerkhove K, Van der Aa B, Baeté H, Meule- 
man B (2009b). Bakermat van duurzaam bosbeheer. Pour le plus grand profit de son excellence [Cradle of sustainable forestry. To the best profit of his excellency]. In: "Miradal - Erfgoed in het Meerdaalwoud en het Heverleebos" [Miradal - Heritage in Meerdaal and Heverlee forest] (Baeté $H$, De Bie $M$, Hermy $M$, Van den Bremt $P$ eds). Davidsfonds, Leuven, Belgium, pp. 139-171. [in Dutch]

Vandekerkhove K, De Keersmaeker L, Walleyn R, Köhler F, Crevecoeur L, Govaere L, Thomaes A, Verheyen K (2011). Reappearance of old growth elements in lowland woodlands in northern Belgium: do the associated species follow? Silva Fennica 45: 909-936. - doi: 10.14214/sf.78 Vandekerkhove $\mathrm{K}$, Thomaes A, Jonsson BG (2013). Connectivity and fragmentation: island biogeography and metapopulation applied to old-growth-elements. In: "Integrative approaches as an opportunity for the conservation of forest biodiversity" (Kraus D, Krumm F eds). European Forest Institute, EFI-ENT, Freiburg, Germany, pp. 104-115. [online] URL: http:// www.efi.int/files/images/eficent/2013_news/int egrate_2013.pdf\#page $=104$

Vandekerkhove $K$, Baeté $H$, Van Der Aa B, De Keersmaeker L, Thomaes A, Leyman A, Verheyen K (2016). 500 years of coppice-with-standards management in Meerdaal Forest (Central Belgium). iForest (early view): e1-e9. - doi: 10.3832/ifor1782-008

Verhulst A (1995). Landschap en landbouw in middeleeuws Vlaanderen [Landcape and agriculture in medieval Flanders]. Gemeentekrediet, Brussels, Belgium, pp. 191. [in Dutch]

Vodka S, Konvicka M, Cížek L (2009). Habitat preferences of oak-feeding xylophagous beetles in a temperate woodland: implications for forest history and management. Journal of Insect Conservation 13: 553-562. - doi: 10.1007/ s10841-008-9202-1

Vodka S, Cížek L (2013). The effects of edge-interior and understorey-canopy gradients on the distribution of saproxylic beetles in a temperate lowland forest. Forest Ecology and Management 304: 33-41. - doi: 10.1016/j.foreco.2013.04. 007

Wermelinger B, Duelli P, Obrist MK (2002). Dynamics of saproxylic beetles (Coleoptera) in windthrow areas in alpine spruce forests. Forest Snow and Landscape Research 77: 133-148. [online] URL: http://wsl.ch/info/mitarbeitende/ wermelin/publikationen/2002_saproxylics.pdf Widerberg MK, Ranius T, Drobyshev I, Nilsson U, Lindbladh M (2012). Increased openness around retained oaks increases species richness of saproxylic beetles. Biodiversity and Conservation 21: 3035-3059. - doi: 10.1007/ s10531-012-0353-8 